\title{
Low-Cost Microwave Reactor For Green Synthesis Of Nanomaterials
}

\author{
Reactor de microondas de bajo costo para la síntesis \\ verde de nanomateriales
}

\author{
Reator de microondas de baixo custo para síntese \\ verde de nanomateriais
}

\section{Leydy Tatiana Figueroa Ariza ${ }^{1}$ Marcela Duarte Espinosa ${ }^{2}$ Beynor Antonio Paez Sierra ${ }^{3}$}

\author{
Received: January $28^{\text {th }}, 2020$ \\ Accepted: March 30 th, 2020 \\ Available: May $4^{\text {th }}, 2020$
}

How to cite this article:

L. T. Figueroa Ariza, M. Duarte Espinosa, B. A. Paez Sierra, "Low-Cost Microwave Reactor for Green Synthesis Of Nanomaterials," Revista Ingeniería Solidaria, vol. 16, no. 2, 2020. doi: https://doi.org/10.16925/2357-6014.2020.02.06

Artículo de investigación. https://doi.org/10.16925/2357-6014.2020.02.06

1 Faculty of Engineering. NanoFab group. Universidad Militar Nueva Granada. Campus Nueva Granada. Kilómetro 2 vía Cajicá-Zipaquirá

ORCID: https://orcid.org/0000-0002-1419-4534

E-mail: u7700113@unimilitar.edu.co

2 Physics Department. NanoFab group. Universidad Militar Nueva Granada. Campus Nueva Granada. Kilómetro 2 vía Cajicá-Zipaquirá

ORCID: https://orcid.org/0000-0002-1761-2447

E-mail: mduartee@unal.edu.co

3 Physics Department. NanoFab group. Universidad Militar Nueva Granada. Campus Nueva Granada. Kilómetro 2 vía Cajicá-Zipaquirá

ORCID: https://orcid.org/0000-0001-8706-9913

E-mail: beynor.paez@unimilitar.edu.co 


\section{Abstract}

Introduction: This contribution is about a low-cost microwave reactor for green synthesis of nanomaterials. The paper reflects research results achieved at the NanoFab group of the Universidad Militar Nueva Granada, within the line of nanophotonics, sensors and nanotechnology. Investigations and analyses were carried out during 2019.

Problem: Conventional synthesis processes usually affect the environment and human health, due to contaminant reagents and generation of by-products.

Objective: The aim of this research is the modification of a microwave oven that assists in the green synthesis of nanomaterials with potential applications in homeland security.

Methodology: In this investigation, the modification of a domestic microwave was carried out. The implemented reactor features a heat exchange unit to reduce volatile elements, and a digital magnetic stirrer for local homogenization. Synthesis begins with a trisodium-citrate solution, continuously stirred at $37^{\circ} \mathrm{C}$. Next, the precursor is mixed with silver-nitrate for 2 minutes. Then, the mixture was treated for 20 minutes in the microwave reactor. Finally, the nanoparticles are recovered.

Results: The homemade microwave reactor is suitable for producing nanoparticles. Particularly, the 20-minute microwave exposure time for the reactants results in a nanoparticle size between $80-90 \mathrm{~nm}$. To probe reaction parameters, impedance spectroscopy analysis is performed. Results revealed that the resistance of the medium of silver nanoparticles is $2.5 \mathrm{ohms}$, while for sodium citrate and nitrate it is 8.8 and 11.8 ohms, respectively.

Conclusion: It is demonstrated that the modified microwave reactor is suitable for nanomaterial production. Lower amounts of solvent are required during nanoparticle synthesis. Microwave synthesis allows for green nanomaterial production with a minor impact on the environment.

Limitation: Homogeneous heating of reactants in a stationary microwave cavity is limited to waveguide design; in this case, to a multimodal-microwave waveguide.

Originality: Low-cost reactor for nanomaterial production and greener synthesis.

Keywords: Microwave reactor, Nanoparticles synthesis, Green chemistry, Impedance spectroscopy

\section{Resumen}

Introducción: El presente trabajo "un reactor de microondas de bajo costo para la síntesis verde de nanomateriales", refleja los resultados de investigación logrados en el grupo NanoFab de la Universidad Militar Nueva Granada. En la línea nanofotónica, sensores y nanotecnología. La investigación y análisis se desarrollaron durante el 2019.

Problema: Los procesos de síntesis convencionales generalmente afectan el ambiente y la salud-humana, debido a los reactivos contaminantes y la generación de subproductos.

Objetivo: Modificar un horno de microondas que permita la síntesis ecológica de nanomateriales con posibles aplicaciones en la seguridad nacional.

Metodología: Al reactor se le acopló con un condensador para reducir los elementos volátiles y un agitador magnético para lograr homogeneización localizada. La síntesis comienza con una solución de citrato trisódico a $37^{\circ} \mathrm{C}$. Luego, se mezcla con el nitrato de plata 2 minutos. La mezcla se trata 20 minutos en el reactor. Finalmente, se recuperan las nanopartículas.

Resultados: El reactor de microondas es adecuado para producir nanopartículas. Particularmente, con el tiempo de exposición de 20 minutos permite tamaños entre $80-90 \mathrm{~nm}$. El análisis de espectroscopía de impedancia 
mostró que la resistencia de las nanopartículas de plata es $2.5 \mathrm{ohms,}$ para el citrato de sodio y el nitrato es 8.8 y 11.8 ohms, respectivamente.

Conclusión: El reactor de microondas modificado es adecuado para la producción de nanomateriales. Se requiere menos solvente durante la síntesis y permite la producción de nanomateriales verdes con un impacto menor en el medio ambiente.

Limitación: El calentamiento homogéneo en la cavidad de microondas se limita al diseño de la guía de ondas, en este caso a la guía del microondas multimodal.

Originalidad: Reactor de bajo costo para producción de nanomateriales y síntesis ecológica.

Palabras clave: reactor de microondas, síntesis de nanopartículas, química verde, espectroscopía de impedancia.

\section{Resumo}

Introdução: Este trabalho "um reator de microondas de baixo custo para a síntese verde de nanomateriais" reflete os resultados da pesquisa alcançada no grupo NanoFab da Universidade Militar de Nova Granada. Na linha de nanofotônica, sensores e nanotecnologia. A pesquisa e a análise foram desenvolvidas durante 2019.

Problema: Os processos convencionais de síntese geralmente afetam o meio ambiente e a saúde humana, devido à contaminação dos reagentes e à geração de subprodutos.

Objetivo: Modificar um forno de micro-ondas que permita a síntese ecológica de nanomateriais com possíveis aplicações em segurança nacional.

Metodologia: 0 reator foi acoplado a um condensador para reduzir elementos voláteis e um agitador magnético para obter homogeneização localizada. A síntese começa com uma solução de citrato de trissódio a 37 - $\mathrm{C}$. Em seguida, é misturado com o nitrato de prata por 2 minutos. A mistura é tratada 20 minutos no reator. Finalmente, as nanopartículas são recuperadas.

Resultados: 0 reator de micro-ondas é adequado para a produção de nanopartículas. Particularmente, com o tempo de exposição de 20 minutos, permite tamanhos entre 80-90 nm. A análise por espectroscopia de impedância mostrou que a resistência das nanopartículas de prata é de 2,5 ohms, para o citrato e nitrato de sódio é de 8,8 e 11,8 ohms, respectivamente.

Conclusão: 0 reator de microondas modificado é adequado para a produção de nanomateriais. É necessário menos solvente durante a síntese e permite a produção de nanomateriais verdes com menos impacto no meio ambiente.

Limitação: 0 aquecimento homogêneo na cavidade da micro-ondas é limitado ao design do guia de ondas, neste caso, a guia multimodal da micro-ondas.

Originalidade: Reator de baixo custo para produção de nanomateriais e síntese ecológica.

Palavras-chave: reator de micro-ondas, síntese de nanopartículas, química verde, espectroscopia de impedância. 


\section{INTRODUCTION}

The development of science has been involved in the discovery of new materials and techniques to make processes more effective and sustainable [1]-[6].

The search for new sources of energy has always been a scientific priority with regards to endothermic chemical reactions. The conventional sources of energy supply in chemical reactions, such as convection heating in electric irons or in burners, has been replaced by synthesis methods where heat is used more efficiently. In particular, microwave-assisted synthesis has been probed to reduce processing time in standard reactions i.e. Fenton-like processes [7].

Especially, when working with isolating materials, microwave heating is called dielectric heating. The reason is based on the ability of the material (precursors) to absorb microwave energy and transform it into heat [1], [8].

In an electromagnetic field, the electrical component causes heating by two main mechanisms; namely, dipolar polarization and ionic conduction [9]. Irradiation of the sample at microwave frequencies results in the dipoles or ions being polarized and aligned in the applied electric field [10]. Simultaneously, when the applied field oscillates, the dipole or ionic field moves to realign with the alternating external electric field and this causes increased kinetic energy in the reactor. Energy is lost in the form of thermal energy through molecular interaction and dielectric loss [4], [6]. The amount of heat generated by this process is directly related to the ability of the matrix to align with the frequency of the applied field. The opposite happens if the dipole does not have enough time to realign with the applied electromagnetic field or is reoriented too quickly with the applied electromagnetic field, resulting in a poor energy to heat conversion.

In recent years, microwave-assisted reactions have opened a world of possibilities in the synthesis of new materials [9]-[12]. The technique offers an easy, clean, fast, efficient and economical protocol for the synthesis of many organic and metallic molecules. Currently, this procedure is considered an important strategy in the use of green chemistry, as it is significantly environmentally friendly. This technology is still used very little in industry.

In this article, a low-cost microwave reactor was designed and developed. The microwave reactor was modified with the integration of a vapor cooler and control for the magnetic stirring speed. As a case study, the reactor was evaluated with the synthesis of silver nanoparticles with distribution sizes between $80 \mathrm{~nm}$ and $90 \mathrm{~nm}$. The effect of the microwave-assisted synthesis time on the electrochemical characteristics of silver nanoparticles was studied. The effect on the electrochemical characteristics was investigated by measuring Electrochemical Impedance Spectroscopy (EIS) 
the impedance characteristics of the silver nanoparticles (AgNPs) can be explained simply by adopting the equivalent electrical circuit.

\subsection{Literature Review}

Current research on nanomaterial production systems is attempting to minimize the effects on the environment, that is, green synthesis; reducing environmental risks in the generation of by-products [13], [14]. This is the case in the most recent investigations where microwave-assisted synthesis has been studied. Since the discovery of microwave synthesis in 1986, hundreds of elements have been developed through microwave-assisted synthesis in fields such as polymers [15], materials [16], biochemistry [17], and nanotechnology [18], [19]. Rapid reduction of reaction times and minimization of side reactions have improved the purity of products when compared to current methods [16], [20]. Therefore, microwave synthesis has been implemented as a green synthesis technique for various materials [21], [22]. The power of microwave irradiation facilitates and optimizes the different stages of the reaction and overcomes many challenges of synthesis kinetics [23].

Microwave synthesis is a nanofabrication route that increases production while being 'green', sustainable, low cost and capable of producing high quality materials [24], contrary to hydrothermal synthesis [25] or synthesis by biological reduction [26] that require processing with greater energy investment and synthesis time. Therefore, microwave-assisted synthesis is an enabled and underlying technology with research potential, ready to be tested in pilot scale production [27].

\section{METHODOLOGY}

\subsection{Microwave oven modifications}

\subsubsection{Condensation of volatile materials}

In the microwave synthesis process, it is important to control the increase in vapor pressure that is generated from volatile precursors. Therefore, an opening was made in the upper part of the microwave, where a condenser or refractor with a reflux water-cooling system could be suspended with the help of a universal support. This is because the reactions at high temperatures generate phase changes due to the latent heat in the reaction. So, it becomes important to prevent overpressure and 
atmospheric pollution in closed reactors, and a heat exchange system was designed (see Figure 1.1) which is adapted to the top of the microwave and condenses the reactor vapors.

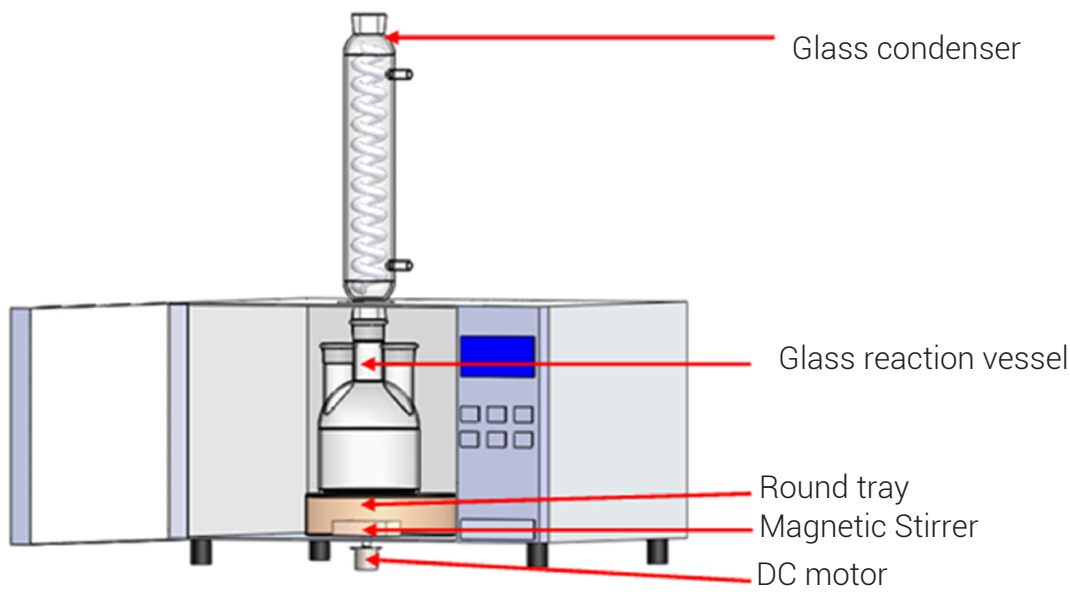

Figure 1.1. Modified microwave reactor design for green synthesis of nanomaterials Reference: the authors

\subsubsection{Case of study: synthesis of silver nanoparticles}

In order to test the home-made microwave reactor, silver nanoparticles were synthesized under different synthesis conditions. The process starts with $250 \mathrm{ml}$ of $10 \mathrm{mM}$ trisodium citrate, heated to $37^{\circ} \mathrm{C}$ via a magnetic stirring heating plate, and then mixed with $250 \mathrm{ml}$ of $10 \mathrm{mM}$ silver nitrate solution for 2 minutes. This mixture was treated in the microwave for 2-20 min. The suspension obtained was centrifuged at 10,000 rpm. The particles were washed with distilled water and dried by lyophilization for later use [28].

\subsubsection{Impedance analysis}

Silver nanoparticles were characterized by impedance spectroscopy. The measurement was carried out in the range of $20 \mathrm{~Hz}$ to $1 \mathrm{MHZ}$ in a cylindrical cell and LCR-4284 of Keysight (Figure 1.2). Capacitance-impedance and parallel resistance-phase angle data were taken.

Electrochemical Impedance Spectroscopy (EIS) is a technique particularly sensitive to small changes in the system, which allows characterizing the electrical properties of the analyte. It consists of the application of a sinusoidal disturbance of 
electric potential of variable frequency to the material studied, and the recording of the current response within an electrochemical cell. The impedance is defined as the ratio between the applied potential and the measured intensity at the output $Z=V / I$; where $V$ is the potential and $I$ is the Intensity [29]. In the analytes or samples, the impedance varies with the frequency of the potential applied in relation to the properties of said sample. From the phase angle and offset measurements related to the amplitude of the response, it is possible to obtain the magnitude of electrochemical impedance as a function of frequency $Z=V \sin (\omega t) / I \sin (\omega t+\phi)$; where $Z$ is impedance measured in Ohms, $V$ is the voltage across the device in units of volts, $I$ is the current through the device in units of Amps, $t$ is time, $\omega$ is the angular frequency and $\phi$ is the phase angle [29].
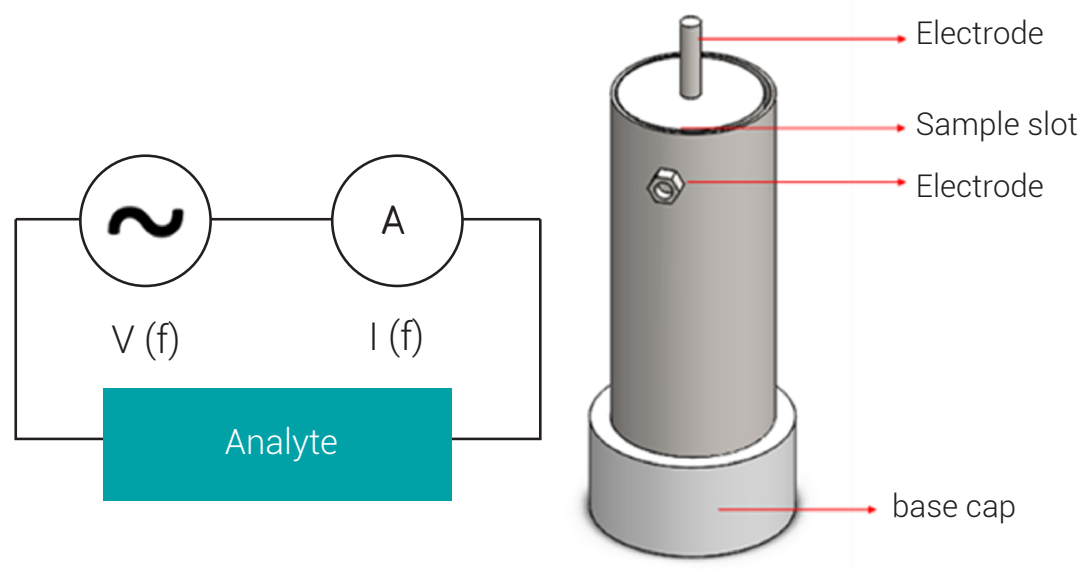

Figure 1.2. Impedance spectroscopy scheme Reference: the authors

\section{RESULTS}

\subsection{Microwave reactor.}

A low-cost microwave reactor for nanomaterial synthesis was developed. The reactor accomplishes condensation of volatile solvents using variable local magnetic stirring for homogeneous mixing of precursors. The microwave reactor is characterized by its ability to perform environmentally friendly synthesis by reducing solvent consumption and reducing the generation of polluting by-products. 


\subsection{Impedance spectroscopy characterization of silver nanoparticles}

Electrochemical impedance spectroscopy (EIS) or impedance methods have gained a dramatic increase in popularity in recent years. EIS, a relatively new and powerful method to characterize the electrochemical properties of materials and their interfaces, is now the method of choice to characterize interfaces in which physical and chemical behavior depends on several different processes that occur at different speeds. Initially applied in the determination of double-layer capacitance and in AC polarography, now it is applied in the characterization of complex electrode processes and interfaces. In theory, any intrinsic property that influences the conductivity of a nanoparticle/solution interface can be examined by impedance measurements.

From the phase angle graph, it is observed that at high frequencies, the suspension of nanoparticles treated with the microwave for 20 minutes presents a non-resistive character (zero angles) since the formation of clusters of silver nanoparticles is observed and exhibits behavior similar to a noble metal that allows for better electrical conduction. It is noted that silver nanoparticles have lower phase angles compared to precursor angles at low frequency. This indicates that highly capacitive particles were formed; which is a passive property close to - $90^{\circ}$ that characterizes corrosive stable materials [30]. Therefore, these silver particles can act as an electric capacitor.

The Bode diagram, which shows how frequency affects the magnitude of impedance and the phase angle (see Figure 1), demonstrates a decreasing trend in impedance as the frequency increases, and then forms a horizontal asymptote with an impedance value lower than that of sodium citrate and silver nitrate; allowing us to conclude that silver particles are less resistive than precursors. This is probably due to the increase in the effective surface area with the formation of silver nanoparticles as reported with other nanometric scale materials [31]. 
A

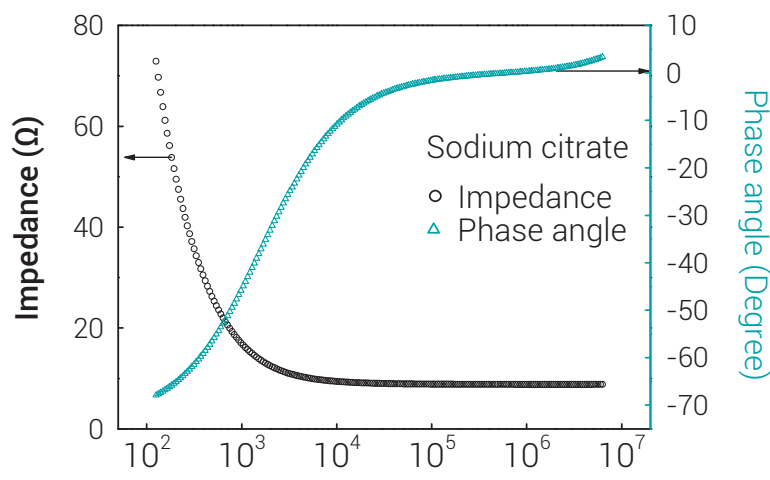

B

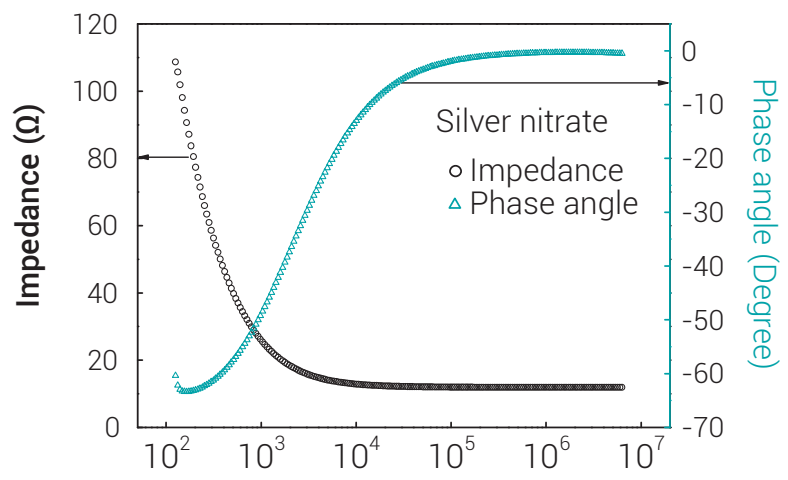

Frequency $(\mathrm{Hz})$

C

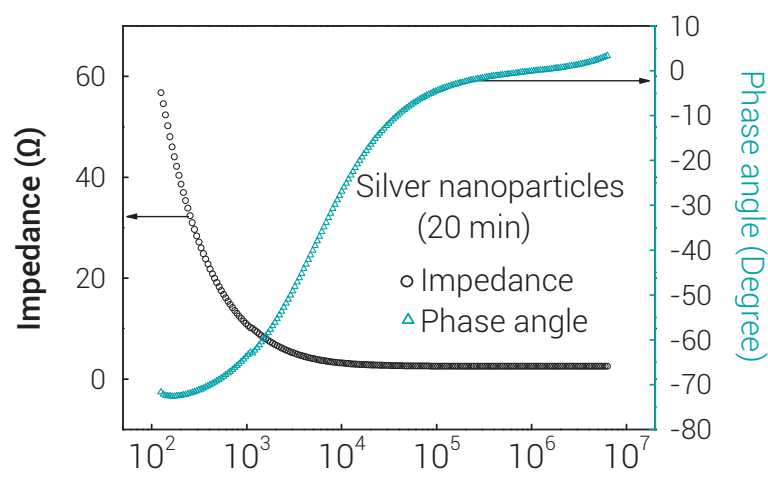

Frequency $(\mathrm{Hz})$

Figure 1. Bode diagram A. Sodium citrate, B. Silver nitrate, and C. Silver Nanoparticles $20 \mathrm{~min}$

Reference: the authors

Figure 2 shows the behavior of the Nyquist curve of the silver nanoparticles, synthesized by microwaves in 20 minutes. A shift to the left is observed with respect to the behavior of the precursor curves (sodium citrate and silver nitrate). In the diagram, 
a linear trend can be seen that, as reported by Aoki et al., 2001 Gassa, Vilche y Ebert, Jüttner, \& Lorenz, 1990 corresponds to the porous morphology of the material that allows for a process of diffusion of electric charge. In addition, as reported by Tran, Huynh, Tran, \& Piro, (2018) the linear upward trend in the Nyquist diagram can be described with a Randles circuit, which is based on an active electrolyte resistance.

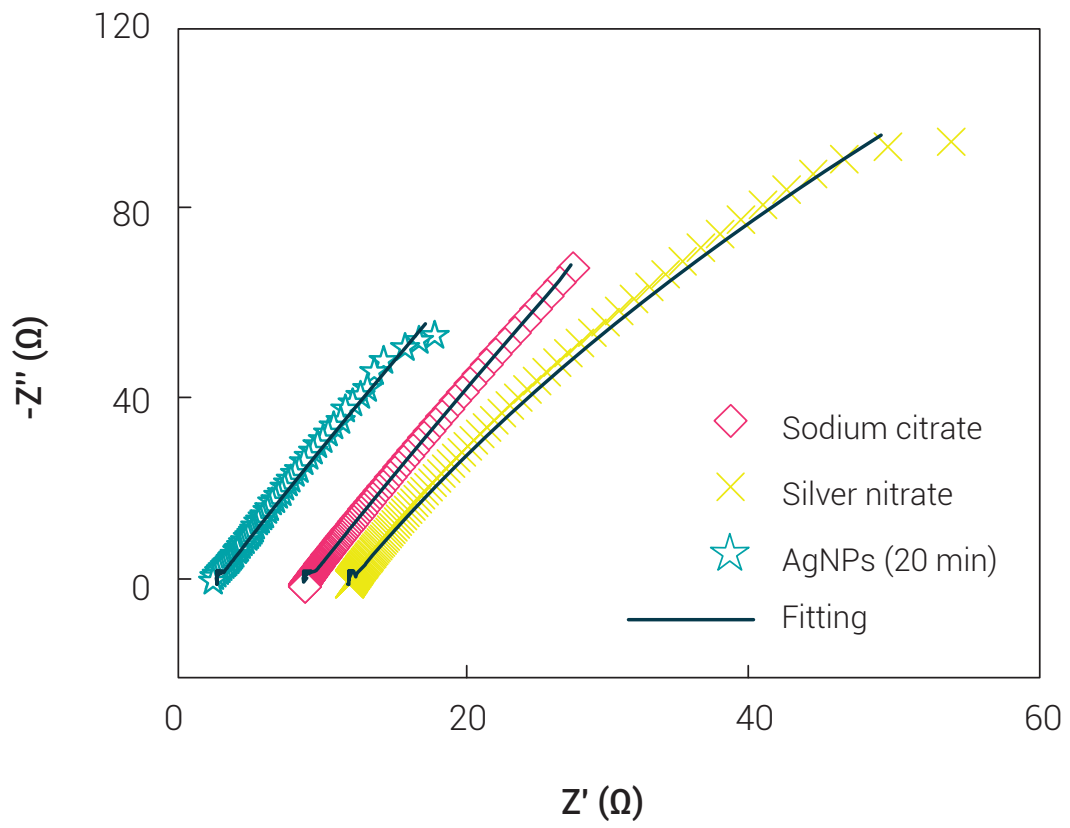

Figure 2. Nyquist diagram of silver nanoparticles.

Reference: the authors

An important aspect of material-electrode characterization is the identification of derived parameters with specific physicochemical processes in the molecules. The ascending linear trend in the Nyquist diagram can be described with a modified Randles circuit (Figure 3), which is based on an active electrolyte resistance that successfully models electrochemical reactions and the state of the nanoparticle interface [31].

The arc impedance element (ZARC) is characterized by describing the Nyquist curves of depressed arc behavior. The Randles circuit that consists of a Constant Phase Element (CPE) and a Resistance (R) in parallel is also called a ZARC element [35]. This is a model representing a polarizable electrode (or an irreversible electrode process), based on the assumptions that a diffusion limitation does not exist, and that a simple single-step electrochemical reaction takes place on the electrode surface. Thus, the impedance can be simplified to a resistance, called the charge-transfer resistance [29]. 


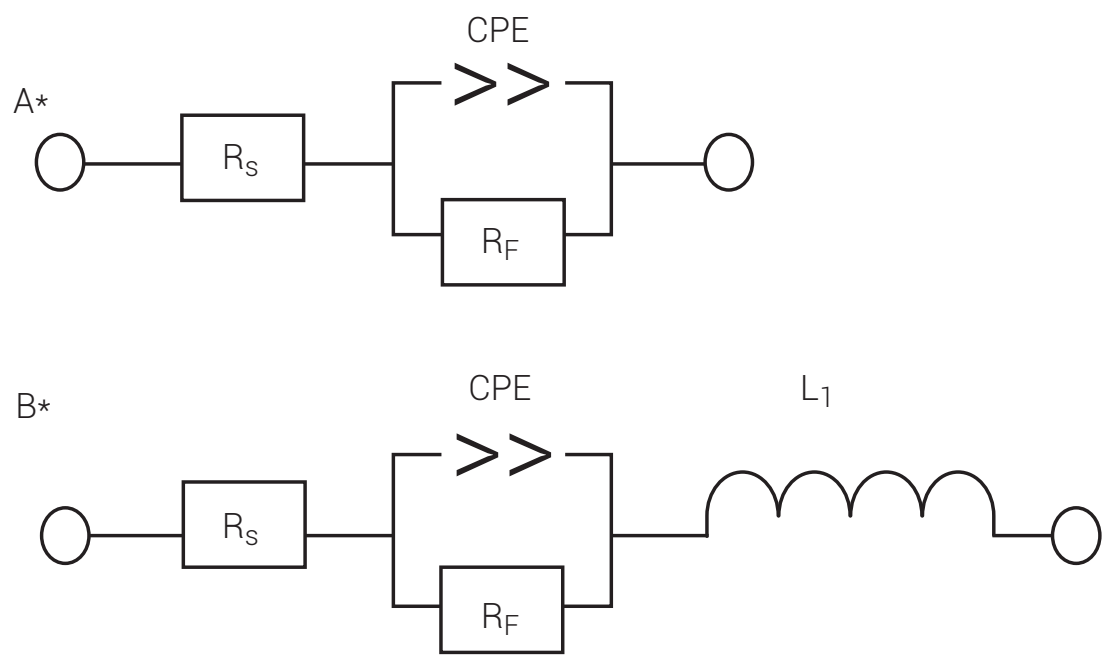

Figure 3. Equivalent circuits: (a) ZARC and (b) ZARC with an inductance circuit. $\mathrm{CPE}$ is the constant phase element, RF is the charge-transfer resistance, $\mathrm{Rs}$ is the series resistance and $\mathrm{L}$ is the Inductance

Reference: the authors

A* ZARC: Randles circuit with CPE modification of Ershler-Randles) ZARC element is characterized by describing the Nyquist curves of depressed arc behavior.

$\mathrm{B} * *$ The circuit with inductance element was used to fit the experimental data of sodium citrate and AgNPs due to induction that occurs at the interfaces of the material thanks to the ionic diffusion of the charge according to the phase angle.

The corresponding equations that describe the equivalent circuits are:

$$
\begin{aligned}
& Z_{E}=R_{S}+\frac{R_{F}}{R_{F}^{2} \omega^{2} Q^{2}+1}+\frac{i R_{F}^{2} \omega^{2} Q^{2}}{R_{F}^{2} \omega^{2} Q^{2}+1} \\
& Z_{E}=R_{S}+\frac{R_{F}}{R_{F}^{2} \omega^{2} Q^{2}+1}+\frac{i R_{F}^{2} \omega^{2} Q^{2}}{R_{F}^{2} \omega^{2} Q^{2}+1}+i \omega L_{l}
\end{aligned}
$$

Where $\omega=2 \pi F$ is the angular frequency, $Q$ is the Constant Phase Element (CPE), $Z_{E}$ is equivalent impedance, $R_{S}$ is series resistance (solution resistance), and $R_{F}$ is parallel resistance (charge transfer resistance).

It is observed that at low frequencies, the imaginary part of the impedance increases in a constant linear fashion, characteristic of capacitive behavior. The results of the fitting of experimental impedance data of precursors and AgNPs are in Table 1. In the same way, in Figure 4A, the citrate sodium and AgNPs for 20 minutes, at 
first sight persisted with a diameter greater than nanometers, given that the increase in thermal treatment disfavors the control of the diameter of the desired material. Sodium citrate is the saline medium where the formation reaction of the AgNPs was carried out. The sodium citrate ions, when disturbed by the alternating current signal, present a diffusion process in the medium transducing the low charge ions to the medium of lower load, so the graph shows an increasing frequency of high frequency at low frequency. Similarly, in the high-frequency region, sodium citrate presents an inductive behavior $\mathrm{L}$.

Table 1. Equivalent circuit results

\begin{tabular}{ccccc}
\hline Circuit element & Units & Sodium citrate & Silver nitrate & AgNPs $^{*}(\mathbf{2 0}$ min) \\
\hline $\mathrm{R}_{\mathrm{s}}$ & $\mathrm{Ohm}$ & 8.81 & 11.8 & 2.504 \\
\hline $\mathrm{R}_{\mathrm{F}}$ & $\mathrm{Ohm}$ & 5406 & 922.1 & 3971 \\
\hline $\mathrm{Q}_{1}$ & $\mathrm{~F} \cdot \mathrm{S}^{\mathrm{n}-1}$ & $0.249 \mathrm{e}-3$ & $0.159 \mathrm{e}-3$ & $0.296 \mathrm{e}-3$ \\
\hline $\mathrm{n}$ & - & 0.8374 & 0.8342 & 0.8442 \\
\hline $\mathrm{L}_{1}$ & $\mathrm{H}$ & $82.8 \mathrm{e}-9$ & - & \\
\hline \multirow{2}{*}{ AgNPs: Silver Nanoparticles synthesized in 20 min. } & & \\
\hline
\end{tabular}

Reference: the authors

Figure 4 shows the capacitance data of the precursors (sodium citrate and silver nitrate) obtained by electrochemical impedance spectroscopy analysis. This data allowed the calculation of capacitive susceptance through Equation 3, where B is capacitive susceptance in siemens, $\mathrm{C}$ capacitance in faradisms and $\mathrm{F}$ frequency in Hertz. These data were normalized to the unit and plotted in Figure 5B.

$$
B=2 * \pi * F * C
$$

Figure 4 shows an increasing behavior in small frequencies, due to a greater presence of free electrons [36]. This decrease in capacitance between $20 \mathrm{~Hz}$ and $1000 \mathrm{~Hz}$ is also attributed to the fact that the electrical circuit that describes the phenomenon, behaves as a pure capacitive element that is comparable to the behavior that nano-compounds evidence, such as the nanostructured polypyrrole that occurs [37]. The results of both impedance and capacitive susceptance show that silver nanoparticles behave as a pure capacitive element, which is ideal in the application of capacitive sensors. However, nanoparticles have lower capacitance when increasing 
the frequency of sodium citrate and sodium nitrate, because the clustering of silver nanoparticles decreases the free transit of electric charges (electrons).

A

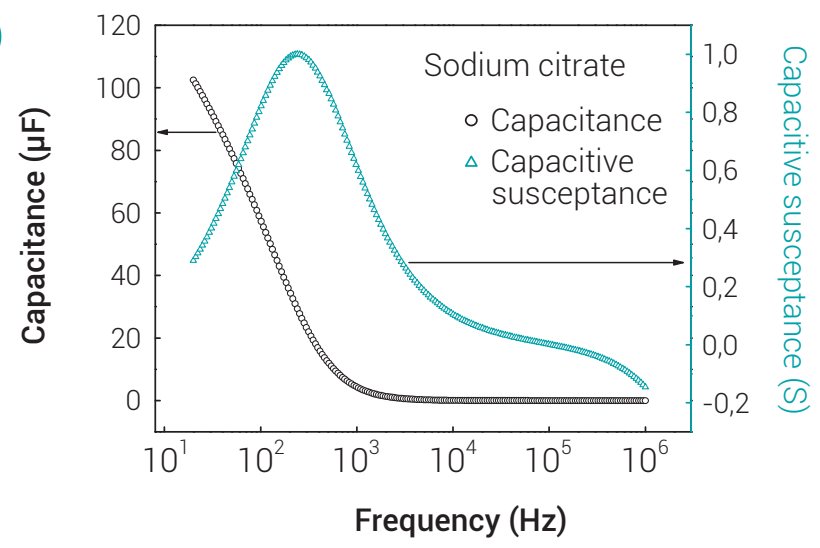

B

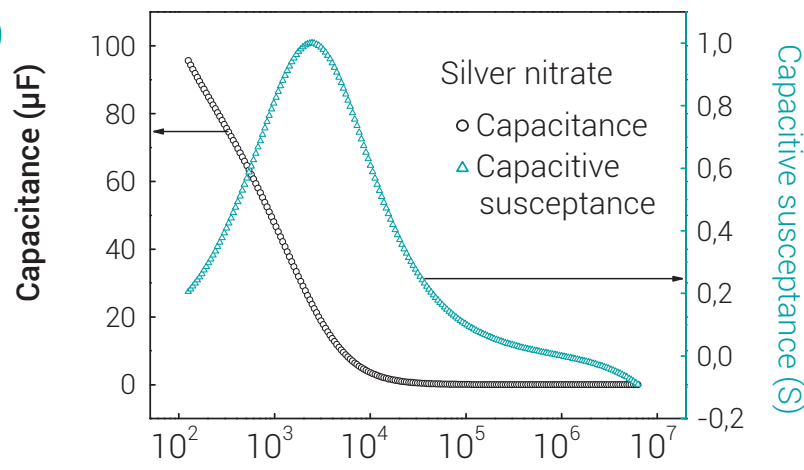

Frequency $(\mathrm{Hz})$

C

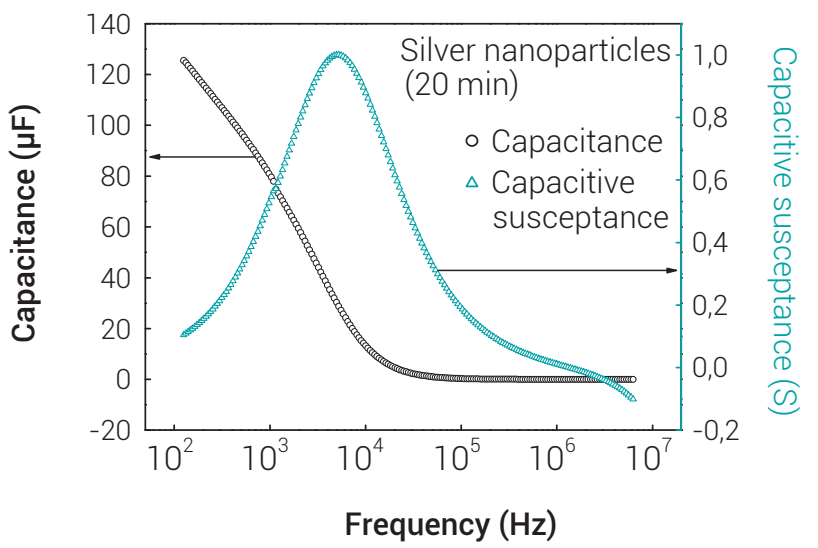

Figure 4. Graphic Capacitance and Capacitive susceptance A. Sodium citrate B. Silver nitrate C. Silver nanoparticles (20 min)

Reference: the authors 


\section{CONCLUSIONS}

- The design and functional prototype of a low-cost reactor for green synthesis of nanomaterials has been developed, which allows control of essential parameters such as homogeneity of reactants, forced solution flow, vapor pressure and generation of contaminating vapors.

- The functionality of the microwave reactor, designed in the case of the synthesis study of silver nanoparticles, was evaluated at 20 min reaction with particle sizes distributed between 80 and $90 \mathrm{~nm}$.

- The electrochemical characteristics of the precursors (reactants) and the AgNPs were evaluated experimentally by means of the Electrochemical Spectroscopy of Impedance in the determination of the equivalent electrochemical circuits, which showed a great inductive influence of the sodium citrate in the AgNPs by the ionic exchange and the phase change.

- The process for the synthesis of AgNPs is fast, novel, ecological and has an excellent electrical property.

\section{ACKNOWLEDGMENTS}

This work was financed by the vice-rectory of research at Universidad Militar Nueva Granada through the grant IMP-CIAS2652.

\section{REFERENCES}

[1] J. Prado-Gonjal y E. Morán, "Síntesis asistida por microondas de sólidos inorgánicos," An. Química, vol. 107, no. 2, pp. 129-136, 2011. [Online]. Available: https://dialnet.unirioja.es/descarga/articulo/3674454.pdf

[2] M. R. Carballido Reboredo, "Síntesis asistida por microondas de compuestos de interés biológico e industrial: haloarenos, fulverenos, tricloropirrolidonas, azoles y flavonoides. Modelado de espectros de absorción electrónica de flavonoides," Universidade de Santiago de Compostela, 2007. [Online]. Available: https://dialnet.unirioja.es/servlet/ tesis?codigo $=108752$

[3] B. L. Hayes, Microwave synthesis, Chemistry at the speed of light, Ilustrada. United Stade: CEM publishing, 2002. [Online]. Available: http://faculty.swosu.edu/tim.hubin/share/ Microwave\%20Synthesis.pdf 
[4] S. Ravichandrany E. Karthikeyan, "Microwave Synthesis-APotential Tool for Green Chemistry," Int. J. ChemTech Res., vol. 3, no. June, 2014. [Online]. Available: https://www.researchgate. net/publication/326667897_Microwave_Synthesis-A_Potential_Tool_for_Green_Chemistry

[5] K. K. Rana y S. Rana, "Microwave Reactors: A Brief Review on Its Fundamental Aspects and Applications," OALib, vol. 1, no. 06, 2014. [Online]. doi: https:doi//10.4236/oalib.1100686

[6] J. M. Miranda Pantoja, J. L. Sebastián, M. Sierra, y J. Margineda, Ingeniería de microondas: técnicas experimentales. Madrid: Prentice Hall, 2002. pp. 221-228.

[7] H. Wang et al., "Rapid decomplexation of Ni-EDTA by microwave-assisted Fenton reaction", Chem. Eng. J., vol. 381, no. August 2019, p. 122703, 2020.[Online]. doi: https://doi.org/10.1016/j.cej.2019.122703

[8] D. Bogdald y A. Prociak, Microwave-Enhanced Polymer Chemistry and Technology. Oxford, UK: Blackwell Publishing Ltd, 2007. [Online]. doi: http://doi.wiley.com/10.1002/9780470390276

[9] R. R. Mishra y A. K. Sharma, "Microwave-material interaction phenomena: Heating mechanisms, challenges and opportunities in material processing", Compos. Part A Appl. Sci. Manuf., vol. 81, 2016. [Online]. doi: http://dx.doi.org/10.1016/j.compositesa.2015.10.035

[10] K. G. Ayappa, H. T. Davis, E. A. Davis, y J. Gordon, "Analysis of microwave heating of materials with temperature-dependent properties," AIChE J., vol. 37, no. 3, mar. 1991. [Online]. doi: http://doi.wiley.com/10.1002/aic.690370302

[11] M. R. Hossan, D. Byun, y P. Dutta, "Analysis of microwave heating for cylindrical shaped objects”, Int. J. Heat Mass Transf., vol. 53, no. 23-24, pnov. 2010. [Online]. doi: http://dx.doi.org/10.1016/j.ijheatmasstransfer.2010.07.051

[12] C. Ching Lau, M. Kemal Bayazit, P. J. T. Reardon, y J. Tang, "Microwave Intensified Synthesis: Batch and Flow Chemistry", Chem. Rec., vol. 19, no. 1, ene. 2019. [Online]. doi: https://onlinelibrary.wiley.com/doi/abs/10.1002/tcr.201800121

[13] L. Faxian, L. Jie, y C. Xueling, "Microwave-assisted Synthesis Silver Nanoparticles and Their Surface Enhancement Raman Scattering," Rare Met. Mater. Eng., vol. 46, no. 9, 2017. [Online]. doi: https://doi.org/10.1016/S1875-5372(17)30204-7

[14] X.-Z. Yuan, C. Song, H. Wang, y J. Zhang, Electrochemical Impedance Spectroscopy in PEM Fuel Cells. London: Springer London, 2010. [Online]. Available: https://link.springer.com/ book/10.1007/978-1-84882-846-9 
[15] J. Hou et al., "Rapid microwave-assisted synthesis of molecularly imprinted polymers on carbon quantum dots for fluorescent sensing of tetracycline in milk", Talanta, vol. 146, [Online]. Available: https://linkinghub.elsevier.com/retrieve/pii/S0039914015302459

[16] T. Liang, J. Qian, Y. Yuan, y C. Liu, "Synthesis of mesoporous hydroxyapatite nanoparticles using a template-free sonochemistry-assisted microwave method", J. Mater. Sci., vol. 48, no. 15, 2013. [Online]. Available: http://link.springer.com/10.1007/s10853-013-7328-3

[17] K. K. Rana y S. Rana, "Microwave Reactors: A Brief Review on Its Fundamental Aspects and Applications," OALib, vol. 01, no. 06, 2014. [Online]. doi:https:// 10.4236/oalib.1100686

[18] J. Yesuraj, S. Austin Suthanthiraraj, y O. Padmaraj, "Synthesis, characterization and electrochemical performance of DNA-templated Bi2MoO6 nanoplates for supercapacitor applications," Mater. Sci. Semicond. Process., vol. 90, no. October 2018, pp. 225-235, 2019. [Online]. Available: https://linkinghub.elsevier.com/retrieve/pii/S136980011830979X

[19] D. Sengupta, B. Roy, y B. Basu, "Microwave-assisted Formation of Organic Disulfides of Biochem ical Significance," Curr. Med. Chem., vol. 24, no. 41, 2016. [Online]. Available: http:// www.eurekaselect.com/141338/article

[20] S. E. Gilliland, J. M. M. Tengco, Y. Yang, J. R. Regalbuto, C. E. Castano, y B. F. Gupton, “Electrostatic adsorption-microwave synthesis of palladium nanoparticles on graphene for improved cross-coupling activity," Appl. Catal. A Gen., vol. 550, ene. 2018. [Online]. Available: https:// linkinghub.elsevier.com/retrieve/pii/S0926860X1730529X

[21] K. Karthik, S. Dhanuskodi, S. Prabu Kumar, C. Gobinath, y S. Sivaramakrishnan, "Microwave assisted green synthesis of $\mathrm{MgO}$ nanorods and their antibacterial and anti-breast cancer activities," Mater. Lett., vol. 206, 2017. [Online]. Available: https://linkinghub.elsevier.com/ retrieve/pii/S0167577X17310418

[22] S. Bano et al., "Microwave-assisted green synthesis of superparamagnetic nanoparticles using fruit peel extracts: Surface engineering, T 2 relaxometry, and photodynamic treatment potential," Int. J. Nanomedicine, vol. 11, pp. 3833-3848, 2016. [Online]. Available: https:// www.dovepress.com/microwave-assisted-green-synthesis-of-superparamagnetic-nanoparticles--peer-reviewed-article-IJN

[23] H. M. Tellez, J. P. Alquisira, C. R. Alonso, J. G. L. Cortés, y C. A. Toledano, "Comparative kinetic study and microwaves non-thermal effects on the formation of poly(amic acid) 4,4'-(hexafluoroisopropylidene)diphthalic anhydride (6FDA) and 4,4'-(hexafluoroisopropylidene) bis(p-phenyleneoxy)dianiline (BAPHF). Reaction activated by micr," Int. J. Mol. Sci., vol. 12, no. 10, pp. 6703-6721, 2011. [Online]. Available: http://www.mdpi.com/1422-0067/12/10/6703 
[24] E. Ruiz Gómezy L. F. Giraldo Jaramillo, "Nanometrología: Impacto en los sistemas de producción,” Cienc. e Ing. Neogranadina, vol. 26, no. 2, pp. 49-72, 2016. [Online]. doi: http://dx.doi. $\operatorname{org} / 10.18359 /$ rcin.1771

[25] Z. G. Wu, L. Li, Z. M. Ren, y L. C. Lv, "Synthesis of palladium nano-squares by polyol-hydrothermal method," Inorg. Chem. Commun., vol. 107, p. 107498, 2019. [Online]. doi: https://doi. org/10.1016/j.inoche.2019.107498

[26] A.Anandaradje,V.Meyappan,I.Kumar,yN.Sakthivel,“MicrobialSynthesisofSilverNanoparticles and Their Biological Potential," en Nanoparticles in Medicine, Singapore: Springer Singapore, 2020, pp. 99-133. [Online]. Available: http://link.springer.com/10.1007/978-981-13-8954-2_4

[27] M. S. Ali y J. A. Priya, "Green Synthesis Of Silver Nanoparticles From Cynodon Dactylon Leaf Extract," Int. J. ChemTech Res. Res, vol. 55, no. 11, pp. 974-4290, 2013. [Online]. Available: http://ijcb.mainspringer.com/5_1/cb501002.pdf

[28] L. Faxian, L. Jie, y C. Xueling, "Microwave-assisted Synthesis Silver Nanoparticles and Their Surface Enhancement Raman Scattering”, Rare Met. Mater. Eng., vol. 46, no. 9, sep. 2017. [Online]. Available: https://linkinghub.elsevier.com/retrieve/pii/S1875537217302047

[29] X.-Z. Yuan, C. Song, H. Wang, y J. Zhang, Electrochemical Impedance Spectroscopy in PEM Fuel Cells. London: Springer London, 2010. [Online]. Available: http://link.springer. com/10.1007/978-1-84882-846-9

[30] L. M. Quej-Ake, A. Contreras, y J. Aburto, "The effect of non-ionic surfactant on the internal corrosion for X52 steel in extra-heavy crude oil-in-water emulsions," Anti-Corrosion Methods Mater., vol. 65, no. 3, pp. 234-248, may 2018. [Online]. Available. https://www.emeraldinsight. com/doi/10.1108/ACMM-03-2017-1770

[31] M. R. Abidiany D. C. Martin, "Experimental and theoretical characterization of implantable neural microelectrodes modified with conducting polymer nanotubes," Biomaterials, vol. 29, no. 9, 2008. [Online]. Available: https://linkinghub.elsevier.com/retrieve/pii/S0142961207009611

[32] L. M. Gassa, J. R. Vilche, M. Ebert, K. Jüttner, y W. J. Lorenz, "Electrochemical impedance spectroscopy on porous electrodes," J. Appl. Electrochem., vol. 20, no. 4, jul. 1990. [Online]. Available: http://link.springer.com/10.1007/BF01008882

[33] I. . Aoki et al., "Ac-impedance and Raman spectroscopy study of the electrochemical behaviour of pure aluminium in citric acid media," Electrochim. Acta, vol. 46, no. 12, mar. 2001. [Online]. Available: https://linkinghub.elsevier.com/retrieve/pii/S0013468601004315 
[34] H. V. Tran, C. D. Huynh, H. V. Tran, y B. Piro, "Cyclic voltammetry, square wave voltammetry, electrochemical impedance spectroscopy and colorimetric method for hydrogen peroxide detection based on chitosan/silver nanocomposite," Arab. J. Chem., vol. 11, no. 4, may 2018. [Online]. Available: https://linkinghub.elsevier.com/retrieve/pii/S1878535216301277

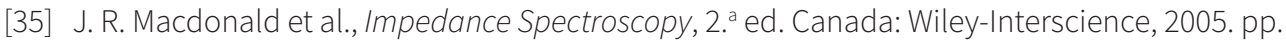
192-200. [Online]. Available: https://www.springer.com/gp/book/9781848828452

[36] J. S. Moon, H. Kim, D.-C. Lee, J. T. Lee, y G. Yushin, "Increasing Capacitance of ZeoliteTemplated Carbons in Electric Double Layer Capacitors," J. Electrochem. Soc., vol. 162, n. ${ }^{\circ}$, 2015. [Online]. Available: https://iopscience.iop.org/article/10.1149/2.0131505jes

[37] M. G. Smitha, B. V. Chaluvaraju, K. N. Anuradha, y M. V. Murugendrappa, "Synthesis, characterization and electrical susceptance studies of Polypyrrole/La0.7Ca0.3MnO3 Nano composites," Mater. Today Proc., vol. 5, no. 1, pp. 3137-3142, ene. 2018. [Online]. Available: https://linkinghub.elsevier.com/retrieve/pii/S2214785318301573 